\title{
EFEKTIVITAS MODUL SISTEM REPRODUKSI BERBASIS BERPIKIR KRITIS TERINTEGRASI NILAI ISLAM DAN KEMUHAMMADIYAHAN TERHADAP KETERAMPILAN BERPIKIR KRITIS
}

\author{
Tutik Fitri Wijayanti ${ }^{1}$ \\ Sulton Na wa wi ${ }^{2}$ \\ ${ }^{1,2}$ ) Pendi dikan Biologi FKIP Uni versitas Muhammadi yah Palembang \\ E-mail: fitri_wijayanti@live.com, sulton.bio@gmail.com
}

\begin{abstract}
This research aims to knowing the effectiveness of reproduction system modules based on critical thinking integrated Islamic and kemuhammadiyahan values. The research method used in the form of quasi experimental, using nonequivalent control group design. Technique of collecting data using test, which was given before and after treatment, then the data obtained was analyzed by using independent sample t-test. The subjects of the study were students of class XI IPA SMA Muhammadiyah 6 Palembang. The result of this research was obtained significance value 0,00<0,05, meaning that module of reproductive system based on critical thinking integrated Islamic value and kemuhammadiyahan effectively improve students' critical thinking skill
\end{abstract}

Kata kunci: Modul, Keterampilan berpikir kritis, Terintegrasi nilai islam, kemuhammadiyahan

Tantangan di era pengetahuan yang semakin dinamis, berkembang, dan semakin maju memerlukan sumber daya manusia yang memiliki keterampilan intelektual tingkat tinggi. Keterampilan intelektual tinggi ditandai keterampilan penalaran yang logis, sistematis, kritis, cermat, dan kreatif serta memiliki kompetisi sikap yang baik dalam mengkomunikasikan gagasan dan memecahkan masalah. Keterampilan-keterampilan yang membekali intelektual siswa tersebut dapat dikembangkan melalui pendidikan. Pada era pengetahuan, modal intelektual, khususnya kecakapan berpikir tingkat tinggi (higher order thinking) merupakan kebutuhan sebagai tenaga kerja yang andal di abad 21 (Galbreath, 1999).

Abad 21 memiliki kemajuan IPTEK yang sangat signifikan jika dibandingkan dengan abad sebelumnya. Muhammadiyah pada abad kedua perjalanannya mengadapi zaman baru kehidupan pascamodern. Kehidupan modern tahap lanjut tersebut searah dengan perkembangan dan perubahan yang spektakuler di berbagai bidang, yang berada dalam pusaran dinamika globalisasi yang membawa ideologi dan kapitalisme dan neoliberalisme global yang masuk ke seluruh relung kehidupan bangsa-bangsa. Salah satu contoh dari kemajuan ini adalah mudahnya dalam mencari informasi melalui dunia internet (cyber society).

Keterampilan berpikir kritis merupakan salah satu bagian dari keterampilan yang dituntut pada abad ke-21. Keterampilan berpikir kritis 
berperan dalam membekali siswa untuk menangani masalah sosial, ilmiah, dan praktis secara efektif di masa mendatang (Snyder, Snyder, Snyder, \& Snyder, 2008).

Keterampilan berpikir kritis adalah proses intelektual dalam pembuatan konsep, mensintesis, menganalisis, mengaplikasikan, dan mengevaluasi berbagai informasi yang didapat dari hasil observasi, pengalaman, refleksi, dimana hasil proses ini digunakan sebagai dasar saat mengambil tindakan (Walker, 2006). Keterampilan berpikir kritis berperan penting dalam kesuksesan hidup siswa di masa yang akan datang dan mampu memecahkan permasalahan.

Keterampilan berpikir kritis siswa Indonesia masih rendah. Indikasinya hasil studi PISA dan TIMSS yang mengalami penurunan dari tahun ke tahun. Rata-rata skor PISA Indonesia pada tahun 2006 berada di peringkat ke-50 dari 57 negara, pada tahun 2009 berada di peringkat ke-60 dari 65 negara, dan pada tahun 2012 Indonesia berada pada peringkat 64 dari 65 negara. Hasil studi untuk TIMSS siswa Indonesia menempati peringkat 32 dari 38 negara pada tahun1999, peringkat 37 dari 46 negara pada tahun 2003, dan peringkat 35 dari 49 negara pada tahun 2007 (Balai Penelitian dan Pengembangan Kementrian Pendidikan dan Kebudayaan, 2011).

Senada dengan pernyataan (Zaqiah, 2013) yang menuliskan hasil survei tentang rendahnya mutu pendidikan di Indonesia berdasarkan hasil laporan Bank Dunia, Indonesia berada pada tingkat terendah se Asia. Siswa mengalami kesulitan dalam konteks soal yang memerlukan analisis dan penalaran. Penelitian (Sadia, 2008) juga menunjukkan bahwa keterampilan berpikir kritis siswa SMA kelas $\mathrm{X}$ di sembilan kabupaten yang ada di Bali, memiliki keterampilan berpikir kritis berkualifikasi rendah. Hal ini terjadi karena kurangnya siswa dilatih untuk memiliki aspek keterampilan berpikir kritis. Aspek berpikir kritis yang dikemukakan (Facione, 2013) antara lain, interpretasi, analisis, eksplanasi, inferensi, evaluasi, dan regulasi diri.

Berdasarkan hasil observasi di SMA Muhammadiyah 6 Palembang, ditemukan permasalahan sebagai berikut: (1) keterampilan berpikir kritis masih belum maksimal; (2) nilai UN materi sistem reproduksi masih belum stabil selama 3 tahun terakhir, yaitu pada tahun tahun 2012/2013 diperoleh 52,78; tahun 2013/2014 diperoleh 40,68.; dan pada tahun 2015/2016 42,22 (Badan Standar Nasional Pendidikan, 2013) (3) bahan ajar yang digunakan belum mengintegrasikan nilai-nilai islam, sehingga siswa masih belum mampu mengaitkan materi biologi yang didapat dengan nilai-nilai islam. Hakikatnya pembelajaran di Muhammadiyah seharusnya siswa mampu memahami nilai-nilai islam dan kemuhammadiyahan melalui kegiatan belajar, meskipun mata 
pelajaran yang sedang diajarkan bukan mata pelajaran agama.

Permasalahan di atas, dapat ditanggulangi melalui aktifitas pembelajaran menggunakan modul pembelajaran berbasis berpikir kritis terintegrasi nilai islam dan kemuhammadiyahan pada materi sistem reproduksi. Tujuan penggunaan modul karena memiliki kelebihan sebagai bahan ajar mandiri, dapat menggantikan fungsi pendidik, sebagai alat evaluasi, dan dapat dijadikan sebagai rujukan bagi siswa (Prastowo, 2012). Modul juga dianggap lebih efektif dan lebih menarik sehingga mampu meningkatkan motivasi siswa dalam belajar (Wijayanti, 2015). Modul berbasis berpikir kritis juga dapat melatihkan keterampilan berpikir kritis, modul diberikan kegiatan yang menuntut siswa untuk menganalisis, mengevaluasi, menjelaskan, menyimpulkan, mengatur diri sendiri, dan interpretasi. Kegiatan yang diberikan dapat berupa diskusi, pengamatan, ataupun pemecahan masalah.

Modul yang terintegrasi nilai islam kemuhammadiyahan, berarti modul yang diselipkan nilai-nilai islam dan kemuhammadiyahan pada kegiatan dan evaluasi pembelajaran. Sumber yang berasal dari Al-Qur'an dan Hadits akan diberikan kepada siswa, selanjutnya siswa akan menganalisis, mengevaluasi, dan mengimplementasikannya dalam kehidupan sehari-hari. Implementasi nilai islam dan kemuhammadiyahan diharapkan mencetak siswa yang memahami islam, juga melahirkan siswa yang menguasai ilmu pengetahuan dan teknologi. Disamping itu juga ada harapan dapat mengubah sikap ke arah yang lebih baik setelah benar-benar terjun ke masyarakat memberikan uswan hasanah. Menggunakan modul berbasis berpikir kritis yang terintegrasi nilai-nilai islam dan kemuhammadiyah sebagai sumber belajar, harapannya siswa akan paham dan memiliki karakter islam yang lebih kuat sehingga terhindar dari perbuatan yang dapat merugikan bagi siswa.

\section{METODE}

Penelitian ini dilaksanakan di SMA Muhammadiyah 6 Palembang pada kelas XI IPA. Peneltian ini merupakan penelitian eksperimental semu menggunakan desain nonequivalent control group design. Kelas eksperimen (kelas XI IPA 1) berjumlah 23 siswa diberi perlakuan dengan menggunakan modul sistem reproduksi berbasis berpikir kritis terintegrasi nilai islam dan kemuhammadiyahan, sementara kelas kontrol (kelas XI IPA 2) berjumlah 24 siswa diberi perlakuan dengan menggunakan modul.

Waktu pelaksanan ini pada bulan Mei-Juni 2017. Dalam penelitian ini, teknik pengumpulan data diperoleh melalui tes menggunakan indikator keterampilan berpikir kritis (pretest-postest). Data yang digunakan adalah data kuantitatif. Data kuantitatif dari kedua kelas ada pretest-postest untuk membandingkan perbedaan keterampilan berpikir kritis pada kedua kelas. 


\section{HASIL}

Penelitian menggunakan 2 kelas XI IPA SMA Muhammadiyah 6 Palembang. Kelas XI IPA 1 adalah kelas eksperimen yang menggunakan modul sistem reproduksi berbasis berpikir kritis terintegrasi nilai islam dan kemuhammadiyahan, kelas XI MIA 2 adalah kelas kontrol yang menggunakan modul sekolah. Data yang diperoleh pada tahap uji lapangan operasional dapat dilihat secara rinci berikut ini:

Tabel 1. Deskriptif Statistik Nilai Pretest \& Postest Kelas XI IPA 1 dan XI IPA 2

\begin{tabular}{|c|c|c|c|c|c|c|}
\hline Kelas & Rentang & $\begin{array}{c}\text { Nilai } \\
\text { minimum }\end{array}$ & $\begin{array}{c}\text { Nilai } \\
\text { maksimum }\end{array}$ & $\begin{array}{l}\text { Rata- } \\
\text { rata }\end{array}$ & $\begin{array}{c}\text { Standar } \\
\text { Deviasi }\end{array}$ & Variansi \\
\hline $\begin{array}{c}\text { Pretest XI } \\
\text { IPA } 1\end{array}$ & 30 & 43 & 73 & 56,52 & 56,52 & 7,89 \\
\hline $\begin{array}{c}\text { Postest XI } \\
\text { IPA } 1\end{array}$ & 20 & 66 & 86 & 73,26 & 73,26 & 5,40 \\
\hline $\begin{array}{l}\text { Pretest XI } \\
\text { IPA } 2\end{array}$ & 40 & 26 & 66 & 51,58 & 8,92 & 79,73 \\
\hline $\begin{array}{l}\text { Postest XI } \\
\text { IPA } 2\end{array}$ & 33 & 43 & 76 & 58,95 & 7,29 & 53,17 \\
\hline
\end{tabular}

Berdasarkan Tabel 1 menunjukkan bahwa Kelas XI IPA 1 memiliki nilai tertinggi pretest 73 dan nilai terendah pretest 43, sehingga rentangnya 30 dengan ratarata 56,52, standar deviasi 7,89 dan varians 62,26. Kelas XI IPA 1 memiliki nilai tertinggi postest 86 dan nilai terendah postest 60 , sehingga rentangnya 20 dengan ratarata 73,26, standar deviasi 5,40 dan varians 29,20. Kelas X MIA 5 memiliki nilai tertinggi pretest 66 dan nilai terendah pretest 26 , sehingga rentangnya 40 dengan ratarata 51,58, standar deviasi 8,92 dan varians 79,73. Kelas $X$ MIA 5 memiliki nilai tertinggi postest 76 dan nilai terendah postest 43, sehingga rentangnya 33 dengan rata- rata 58,95 , standar deviasi 7,29 dan varians 53,17 .

Dapat disimpulkan bahwa kelas yang menggunakan modul sistem reproduksi berbasis berpikir kritis terintegrasi nilai islam dan kemuhammadiyahan memperoleh rata-rata pretest dan postest yang tinggi dibandingkan kelas yang menggunakan modul sekolah.

Data pretest dan postest dari kelas XI IPA 1 dan XI IPA 2 dianalisis dengan Uji Independent sample T-Test untuk mengetahui efektivitas modul berbasis berpikir kritis terintegrasi nilai islam dan kemuhammadiyahan pada materi lingkungan dengan didahului dengan uji prasyarat parametrik yaitu uji normalitas dan homogenitas. 
Tabe12. Uji Prasyarat Statistik Parametrik

\begin{tabular}{|c|c|c|c|c|c|}
\hline Perlakuan & Uji & Jenis Uji & Hasil & Keputusan & Kesimpulan \\
\hline \multirow[t]{2}{*}{$\begin{array}{l}\text { Eks perimen } \\
\text { (XI IPA 1) }\end{array}$} & Normalitas & $\begin{array}{l}\text { Shapiro- } \\
\text { Wilk }\end{array}$ & Sig pretest $=0,196$ & $\mathrm{H}_{0}$ diterima & $\begin{array}{l}\text { Nilai berdis tribusi } \\
\text { normal }\end{array}$ \\
\hline & & & Sig postest $=0.107$ & $\mathrm{H}_{0}$ diterima & $\begin{array}{l}\text { Nilai berdis tribusi } \\
\text { normal }\end{array}$ \\
\hline \multirow[t]{2}{*}{$\begin{array}{l}\text { Kontrol } \\
\text { ((XI IPA 2) }\end{array}$} & Normalitas & $\begin{array}{l}\text { Shapiro- } \\
\text { Wilk }\end{array}$ & Sig pretest $=0.135$ & $\mathrm{H}_{0}$ diterima & $\begin{array}{l}\text { Nilai berdis tribusi } \\
\text { normal }\end{array}$ \\
\hline & & & Sig postest $=0.864$ & $\mathrm{H}_{0}$ diterima & $\begin{array}{l}\text { Nilai berdis tribusi } \\
\text { normal }\end{array}$ \\
\hline Semua & Ho mogen & Levene's test & Sig pretest $=0.956$ & $\mathrm{H}_{0}$ diterima & Nilai ho mogen \\
\hline Kelas & Itas & & Sig postest $=0.136$ & $\mathrm{H}_{0}$ diterima & Nilai ho mogen \\
\hline
\end{tabular}

$\begin{array}{llll}\text { Berdasarkan } & \text { Tabel } 2 & \text { (kelas kontrol) berdistribusi normal } \\ \text { menunjukan bahwa pretest dan } & \text { dan homogen karena taraf signifikasi } \\ \text { posttest pada kelas XI IPA 1 (kelas } & \text { lebih dari 0.05 dan dapat dilanjutkan } \\ \text { eksperimen) dan kelas XI IPA } 2 & \text { pada Uji Independent Sampel T-Test. }\end{array}$

Tabel3. Uji Prasyarat Statistik Parametrik

\begin{tabular}{|c|c|c|c|c|}
\hline Variabel & $\mathbf{F}$ & $\begin{array}{l}\text { Taraf } \\
\text { signifikasi }\end{array}$ & $\begin{array}{l}\text { Keputusa } \\
\text { n }\end{array}$ & Kesimpulan \\
\hline $\begin{array}{l}\text { Kelas } \\
\text { eksperime } \\
\text { n, kontrol }\end{array}$ & 2 & $\begin{array}{l}0.000 \\
(\operatorname{sig}<0.05)\end{array}$ & $\mathrm{H}_{0}$ ditolak & $\begin{array}{l}\text { Ada perbedaan } \\
\text { nilai postest antara } \\
\text { kelas eksperimen, } \\
\text { kontrol dan model }\end{array}$ \\
\hline
\end{tabular}

Hasil Uji Independent Sampel T-Test menunjukkan terdapat perbedaan nilai postes antara kelas eksperimen dengan kontrol karena taraf signifikasi lebih kecil 0.05 , sehingga disimpulkan bahwa terdapat perbedaan nilai postes antara kelas yang menggunakan modul sistem reproduksi berbasis berpikir kritis terintegrasi nilai islam dan kemuhammadiyahan dengan modul sekolah.

\section{PEMBAHASAN}

Efektivitas modul sistem reproduksi berbasis berpikir kritis terintegrasi nilai islam dan kemuhammadiyahan didasarkan pada ada tidaknya kenaikan keterampilan berpikir kritis. Efektivitas modul juga dilihat dari perbedaan data signifikansi antara sebelum dan sesudah penerapan modul sistem reproduksi berbasis berpikir kritis terintegrasi nilai islam dan 
kemuhammadiyahan.

Proses

pembelajaran yang optimal akan berkorelasi dengan hasil belajar siswa, karena pada dasarnya belajar merupakan proses siswa dalam membangun pengetahuannya sendiri melalui berbagai stimulus dan daya dukung. Dalam pandangan konstruktivis, belajar adalah proses yang aktif yaitu siswa membangun sendiri pengetahuan yang dimiliki. Pengetahuan dibentuk oleh siswa melalui pemecahan masalah yang dikaitkan dengan lingkungan, hal tersebut erat kaitannya dengan pengalaman dalam kehidupan seharihari sehingga diharapkan siswa memperoleh pembelajaran yang bermakna. Proses pembelajaran yang optimal akan mampu meningkatkan keterampilan berpikir kritis.

Hasil Uji Independent Sampel $t$-Test menunjukkan bahwa terdapat perbedaan nilai postest antara kelas eksperimen yang menggunakan modul sistem reproduksi berbasis berpikir kritis terintegrasi nilai islam dan kemuhammadiyahan, dengan kelas kontrol yang menggunakan bahan ajar di sekolah. Hal ini dapat dilihat dari nilai signifikasi 0,00 lebih kecil dari 0,05. Uji Independent Sampel t-Test disimpulkan bahwa modul sistem reproduksi berbasis berpikir kritis terintegrasi nilai islam dan kemuhammadiyahan efektif untuk melatihkan keterampilan berpikir kritis pada materi ajar sistem reproduksi manusia.

Pembelajaran

yang

menggunakan modul menurut
(Prastowo, 2012) akan meningkatkan keterampilan siswa untuk belajar secara mandiri tanpa tergantung kehadiran guru. Hal ini terjadi karena di dalam modul memiliki arahan bagaimana untuk menguasai poin penting di dalam materi, kegiatan yang harus dilakukan oleh siswa dalam mengkonstruk materi, dan uraian materi yang disusun lebih kompleks dan mudah dipahami oleh siswa.

Meningkatkan keterampilan berpikir kritis siswa melalui modul dianggap lebih efektif dibanding dengan melatihkan keterampilan berpikir kritis melalui kegiatan belajar mengajar secara langsung tanpa modul. Alasannya karena di dalam modul terdapat indikator, materi, aktivitas, dan latihan soal yang sangat jelas terpetakan dan disesuaikan dengan aspek berpikir kritis. Apabila hanya melatihkan melalui kegiatan belajar saja tanpa menggunakan modul, tentunya siswa kurang mengerti bagaimana cara untuk mengukur keterampilan yang harus dicapai melalui indikator dan latihanlatihan soal.

Nilai rata-rata yang diperoleh oleh kelas kontrol saat pretes adalah 51,58 dan nilai postes diperoleh 58,95, dengan peningkatan sebesar $7,37 \%$. Nilai rata-rata yang diperoleh kelas eksperimen saat pretes adalah 56,52 dan nilai postes diperoleh 73,26 dengan peningkatan sebesar $16,74 \%$. Nilai rata-rata kelas eksperimen yang lebih tinggi dibanding kelas kontrol menunjukkan jika modul sistem reproduksi berbasis berpikir kritis 
terintegrasi nilai islam dan kemuhammadiyahan efektif untuk meningkatkan keterampilan berpikir kritis. Sesuai dengan yang dinyatakan oleh (Hasruddin, 2009) bahwa siswa akan memiliki pemahaman yang mendalam bila pada proses pembelajaran menekankan keterampilan berpikir kritis. Melalui keterampilan berpikir kritis, siswa diberi kesempatan menggunakan pemikiran dalam tingkatan yang lebih tinggi. Untuk memaksimalkan keterampilan berpikir kritis ini maka pembelajaran seharusnya memberdayakan keterampilan berpikirnya.

Modul sistem reproduksi berbas is berpikir kritis terintegrasi nilai islam dan kemuhammadiyahan efektif melatihkan keterampilan berpikir kritis dibandingkan dengan bahan ajar di sekolah, karena modul sistem reproduksi berbasis berpikir kritis terintegrasi nilai islam dan kemuhammadiyahan disusun secara sistematis berdasarkan aspek tujuan, materi, kegiatan, soal evaluasi yang menggunakan indikator berpikir kritis pada dimensi fakta, konsep, serta prosedural. Selain itu kegiatan pembelajaran, materi, dan evaluasi dalam modul dilengkapi dengan nilai islam dan kemuhammadiyahan yang bersumber dari Ayat Al-Quran dan Hadist. Sehingga siswa tidak hanya belajar terkait materi sistem reproduksi saja tetapi siswa juga belajar menganalisis permasalahan atau persoalan dalam sistem reproduksi manusia dikaitkan dengan ayat Al-Quran dan hadist, kemudian memberikan solusinya dan diaplikasikan dalam kehidupan sehari-hari.

Selama kegiatan penelitian berlangsung, siswa di kelas eksperimen juga terlihat sangat antusias. Dimulai dengan diskusi kelompok hingga presentasi kelompok. Setiap siswa dari perwakilan kelompok selalu ingin menyampaikan pendapat. Hal ini dapat terjadi karena materi yang diajarkan juga diintegrasikan dengan nilai al islam dan kemuhammadiyahan. Akibatnya siswa tidak hanya membahas materi dalam segi sains, tapi juga mengaitkannya dengan kehidupan sehari-hari, nilai-nilai islam, bahkan juga mengaitkan dengan kehidupan antar umat beragama di Indonesia, dan kehidupan di negara lain yang mayoritas bukan agama islam. Kegiatan belajar yang begitu asyik seringkali membuat siswa lupa akan waktu, bahkan waktu belajar dianggap sangat kurang.

Kelas kontrol yang kebetulan pembelajaranya saat itu juga menggunakan metode diskusi presentasi, namun terdapat perbedaan yang sangat nyata. Di kelas kontrol siswa yang aktif hanya siswa yang ditugaskan untuk mempresentasikan materi kemudian membuat sesi tanya jawab. Jadi siswa yang kebetulan tidak mendapatkan tugas presentasi hanya akan mendengarkan materi, dan bahkan banyak yang mengobrol, dan bermain HP. Meskipun di kelas eksperimen juga menggunakan metode diskusi dan presentasi, di 
kelas eksperimen tidak membuat siswa tertentu saja yang aktif. Sesuai dengan kegiatan pembelajaran yang dibuat dalam modul berbasis berpikir kritis terintegrasi nilai al islam dan kemuhammadiyahan, kegiatan diskusi dibuat untuk memecahkan berbagai permasalahan yang ada di dalam modul kemudian mempresentasikan solusi atau jawaban yang mereka temukan. Di presentasi inilah yang sangat terlihat perbedaannya, sis wa di kelas eksperimen terlihat sangat antusias dan saling berebut untuk mengkomunikasikan pendapat, sanggahan, pertanyaan, dan jawaban masing-masing kelompok.

Penelitian (Brooke, 2006) menjelaskan bahwa berpikir kritis juga dapat ditingkatkan dengan menghadirkan kasus dalam pembelajaran sehingga siswa terdorong untuk menggunakan keterampilan berpikir kritisnya ketika menganalisis dan memecahkan kasus yang tersedia. Sejalan dengan itu hasil penelitian (Hanson \& Wolfskill, 2000) menyatakan bahwa pemecahan masalah melalui kerja tim dapat meningkatkan keterampilan siswa dalam berpikir kritis, mengurangi miskonsepsi, mencari informasi dan mengkonstruksi pemahaman secara aktif serta terampil memberikan alasan tingkat tinggi.

Modul sistem reproduksi berbasis berpikir kritis terintegrasi nilai islam dan kemuhammadiyahan mendorong siswa memiliki keterampilan berpikir kritis, diantaranya: (1) keterampilan interpretasi yang berperan dalam mengamati sifat, menafsirkan data, dan mengekspresikan makna dari berbagai pengalaman; keterampilan analisis yang berperan dalam mengidentifikasi hubungan antar konsep untuk mengekspresikan keyakinan, penilaian atau alasan; (3) keterampilan evaluasi yang berperan dalam menilai kredibilitas pernyataan dan representasi dari orang lain serta menilai kekuatan logis dari pernyataan, deskripsi atau pertanyaan; (4) keterampilan menyimpulkan (inferensi) yang berperan dalam menarik kesimpulan atau hipotesis berdasarkan fakta, penilaian, keyakinan, prinsip-prinsip, konsep-konsep atau representasi; (5) keterampilan menjelaskan (eksplanasi) yang berperan dalam mendeskripsikan fenomena, hubungan kausal atau proses, dan argumen penguat menggunakan data empiris sebagai dasar penjelasan; (6) dan keterampilan pengaturan (regulasi) diri berperan dalam mengarahkan diri untuk membantu siswa dalam mengelola pikiran, perilaku, dan emosi supaya berhasil mengarahkan pengalaman belajar untuk mencapai tujuan. Seseorang dengan pemikiran kritis biasanya memiliki rasa ingin tahu, berpikiran terbuka, fleksibel, jujur dalam menghadapi sesuatu, bijaksana dalam penilaian, mempertimbangkan kembali dengan wawasan yang lain, rajin dalam mencari informasi yang relevan, wajar dalam memilih kriteria, fokus saat melakukan penyelidikan, dan gigih dalam mencari informasi 
setepat mungkin tentang subjek (Facione, 2013).

Adanya peningkatan aspek berpikir kritis menunjukan keberhasilan penelitian dalam mengembangkan produk modul sistem reproduksi berbasis berpikir kritis terintegrasi nilai islam dan kemuhammadiyahan, sesuai tuntutan abad 21 yang memungkinkan siswa untuk menangani masalah sosial, ilmiah, dan praktis secara efektif di masa mendatang (Snyder et al., 2008). Modul sistem reproduksi berbasis berpikir kritis terintegrasi nilai islam dan kemuhammadiyahan akan melatih siswa dalam berpikir untuk menyelesaikan permasalahan tidak hanya terbatas pada konteks modul saja, namun permasalahan lain yang ada hubungannya dengan kehidupan sehari-hari. Kadangkala, siswa dihadapkan pada situasi masalah, informasi yang tidak lengkap dan pertanyaan yang belum ada jawabannya. Rancangan tersebut dihadapkan kepada siswa untuk melatihkan siswa dalam mendefinisikan, menguraikan masalah, membuat hipotesis, menelusuri data dan mengembangkan solusi. Oleh karenanya, siswa dituntut untuk melakukan proses berpikir ilmiah melalui berpikir kritis terutama keterampilan menganalisis, yang meliputi: keterampilan menguji ide, mengenali argumen dan mengenali alasan dan pernyataan (Facione, 2013). Proses berpikir tersebut dilalui siswa agar membekali dalam kehidupannya kelak di masyarakat.

\begin{abstract}
Nilai Al islam dan kemuhammadiyahan yang diintegrasikan ke dalam modul, harapannya dapat membuat siswa mampu mengaitkan setiap aspek dalam kehidupan dengan sikap spiritualnya. Selalu bertambah rasa syukurnya dan ketaqwaannya. Berpikir kritis dianggap mampu membuat siswa berpikir lebih maju dalam menghadapi berbagai tantangan di era modern. Sikap spiritual yang berlandaskan Al-Quran dan Hadist akan mendampingi siswa menentukan suatu keputusan dengan benar.
\end{abstract}

\section{KESIMPULAN}

Modul sistem reproduksi berbasis berpikir kritis terintegrasi nilai islam dan kemuhammadiyahan efektif untuk melatihkan keterampilan berpikir kritis dibandingkan kelas yang menggunakan bahan ajar di sekolah karena hasil uji statistik diperoleh signifikansi $0,00<0,05$ yang menyatakan adanya perbedaan secara signifikan

\section{ACKNOWLEDMENT}

Penulis mengucapkan terima kasih kepada Majelis Diktilitbang Pimpinan Pusat Muhammadiyah yang telah bersedia mendanai penelitian dan pengembangan modul berbasis berpikir kritis terintegrasi Al-Islam dan Kemuhammadiyahan Muhamadiyahan.

\section{DAFTAR RUJUKAN}

Badan Standar Nasional Pendidikan. (2013). Laporan Hasil Ujian 
Nasional. Jakarta: Puslitbang Kemdikbud.

Balai Penelitian dan Pengembangan

Kementrian Pendidikan dan

Kebudayaan. (2011). Progamme

for International Student

Assesment (PISA) dan Trends in

International Mathematics and

Science Stud (TIMSS).

Brooke, S. L. (2006). Using the Case

Method to Teach Online Classes:

Promoting Socratic Dialogue and Critical Thinking Skills. International Journal of Teaching and Learning in Higher Education, 18(2), 142149.

Facione, P. A. (2013). Critical Thinking, What It Is and Why I Counts. California: California Academic Press.

Galbreath, J. (1999). Preparing the 21st Century Worker: The Link between Computer-based Technology and Future Skills Sets. Educational Technology, 39, 14-22. Retrieved from http://eric.ed.gov/?id=EJ595512

Hanson, D., \& Wolfskill, T. (2000). Process Workshops - A New Model for Instruction. J. Chem. Educ., $\quad 77(1), \quad 120$. https://doi.org/10.1021/ed077p1 20

Hasruddin. (2009). Memaksimalkan Kemampuan Berpikir Kritis melalui Pendekatan Kontekstual. Jurnal Taburasa PPS UNIMED, 6(1), 48-60.

Prastowo. (2012). Panduan Kreatif Membuat Bahan Ajar Inovatif. Yogyakarta: Diva Press.
Sadia, I. W. (2008). Model pembelajaran yang efektif untuk meningkatkan keterampilan berpikir kritis. Jurnal Pendidikan Dan Pengajaran, 2, 219-237.

Snyder, L. G., Snyder, L. G., Snyder, M. J., \& Snyder, M. J. (2008). Teaching Critical Thinking and Problem Solving Skills. The Delta Pi Epsilon Journal, L(2), 90-100.

https://doi.org/10.1023/A:10096 82924511

Walker, P. (2006). Skill Development and Critical Thinking in Higher Education. Teaching in Higher Education, 4(4), 531-547. Retrieved from srhe.tandfonline.com

Wijayanti, T. F. (2015). Pengembangan Modul Berbasis Berpikir Kritis Disertai Argument Mapping pada Materi Sistem Pernapasan untuk Meningkatkan Kemampuan Berpikir Kritis Siswa Kelas XI SMAN 5 Surakarta. Universitas Sebelas Maret Surakarta. Retrieved from https://digilib.uns.ac.id/

Zaqiah, K. Y. (2013). Implementasi Pembelajaran Berbasis Kemampuan Otak (Brain Based Learning) untuk Meningkatkan Kemampuan Berpikir Kritis (Studi Kuasi Eksperimen pada Siswa Sekolah Dasar di Bandung. Universitas Pendidikan Indonesia. Retrieved from http://repository.upi.edu/ 